\title{
Building confidence: the transition from student to professor
}

\section{Elaine Fuchs}

My turning point as a scientist was the offer of an assistant professorship to join 15 male colleagues in the Biochemistry Department at the University of Chicago. How I arrived at this position is more circuitous.

Like many other kids who grew up in the cornfield suburbs outside Chicago, playing in swamps and fields was far more interesting than organized sports, particularly when only three other kids lived within earshot of our house. Unlike those kids' parents, my father was a geochemist and my aunt, a biologist at Argonne National Labs. Both were graduates of the University of Chicago, where I later received an offer.

My father encouraged me to be an elementary school teacher; it was my mother - a homemaker with artistic, musical and gardening talents who contended that since I cooked well, I'd make a fine chemist. I didn't believe her. However, I did major in Chemistry at the University of Illinois. As one of three women in a class of 200 physics students, I felt that I had to study hard to be recognized. I pestered the graduate teaching assistants, who explained the science and also taught me how to juggle tennis balls. After each exam, I always anticipated failure, but usually received the best grade and became a good juggler.

On graduating, I hoped to enter the Peace Corps, an American programme for volunteer work in the developing world. I applied to graduate school as a default pathway, exerting my creativity by submitting a two page essay outlining my reasons for refusing to take the graduate school entrance examinations. My options turned out to be graduate school or Idi Amin, Uganda and the Peace Corps.

Without having any college biology, I began Princeton's graduate programme in Biochemistry.

Elaine Fuchs is the Rebecca C. Lancefield Professor of Mammalian Cell Biology and Development, Howard Hughes Medical Institute, The Rockefeller University, NY 10065, USA. E-mail: fuchslb@rockefeller.edu
Marc Kirschner's lectures on differentiation were counter to my maths professors' views. Bruce Alberts only took the best students - I wasn't among them. So I chose Charles Gilvarg, an exceptionally smart but demanding advisor researching bacterial sporulation.

Biological equations had too many variables. I worked day and night without solving any problems. I was, however, developing my tennis backhand and broadening my horizons with inexpensive trips to India, Nepal, Bolivia, Peru, Egypt and Turkey. Closer to Princeton, I tasted the pleasures of New York City, discovering restaurants, art and music.

Every now and then an experiment worked, yielding a fresh and exciting way to counter the agony of defeat. I began to enjoy designing my own experiments. I defended my $\mathrm{PhD}$ with a modicum of confidence and with a determination to work at the interface of biology and medicine. I chose to work at Massachusetts Institute of Technology (MIT) with Howard Green, who devised methods to culture human stem cells - epidermal keratinocytes - under conditions where they could be maintained and propagated straight from tissue.

On arrival, I was handed a bucket of rat submaxillary glands and asked to purify EGF (epidermal growth factor) for the lab. I was then asked to search through urine for new growth factors. Perhaps Howard misinterpreted 'P-Chem' on my resume. Left to my own devices, I began to identify keratins, their mRNAs and their program of gene expression, as a means to explore epidermal differentiation. I began embarking upon my own trajectory.

I ventured upstairs, downstairs and across the street. Sheldon Penman's postdocs were the mRNA experts. Gobind Khorana's postdocs taught me to make Oligo dT cellulose. London's postdocs were skilled at isolating rabbit reticulocytes for in vitro translations. Jim Rothman was the ${ }^{32}$ P-labelling expert, Richard Hynes shared my interest in comparing vimentin and keratin, Bryan Roberts at Brandeis was Zen master of methyl mercury gels and the David Baltimore and Phil Sharp labs were embarking on DNA recombinant technology. I thrived in the environment at MIT. My experiments were working. While maintaining my interests in music, art and travelling, I fuelled my passion for science.

In my second year at MIT, Charlie Gilvarg nominated me for a faculty position at the University of Chicago. I was flabbergasted, but overjoyed. An even bigger surprise was the invitation for an interview: a free trip home and a chance to practice being interviewed!

Snow was everywhere. I always disliked Chicago's cold weather, but when the city is hit by a major snowstorm, it is beautiful. My seminar seemed to go smoothly. My discussions with famous scientists were a treat. The lack of expectations was a recipe for relaxation.

Months passed. Fellow MIT postdocs received rejection notices. I wondered if mine had been lost in the mail. After receiving an offer that year, I wondered whether Chicago had been impressed with my 'confidence' in not having applied elsewhere.

My father always inspired me to strive to do better. Charlie Gilvarg instilled in me the importance of designing a well-controlled experiment. Marc Kirschner, Bruce Alberts and my other professors at Princeton inspired in me the excitement of the looming revolution in recombinant DNA technology. They exemplified why originality and unconventional thinking are so critical in moving science forward. Howard Green reinforced these lessons. MIT generated an exhilarating environment that stimulated every brain cell I had. It made it easy for those with initiative to thrive. But the offer from the University of Chicago gave me the opportunity to have my own lab, affording me the possibility to pursue my passion. 